\title{
Changes in Marine Seafood Consumption in Tokyo, Japan
}

\section{Mudanças no consumo de pescado marinho em Tóquio, Japão}

\author{
Tatiana Maria Cecy GADDA* \\ Peter John MARCOTULLIO**
}

\begin{abstract}
This article examines the historical trends of Tokyo's marine seafood consumption and tensions over how to promote urban sustainable consumption. Despite overwhelming evidence that global fish stocks are depleting, the Tokyo Metropolitan Government has not advanced an agenda to directly support sustainable seafood consumption. In this vacuum national government policies, increasing wealth, changes in preferences and private initiatives have promoted the consumption of ever larger amounts of seafood. Notwithstanding these forces, however, consumption patterns since the 1970s have changed in unpredictable ways. The per capita proportion consumed of prized, high trophic level and high status seafood, such as carnivorous fish, is declining while the consumption of other types of seafood from lower trophic levels is increasing. Moreover, seafood prices seem to play little role in these trends. Despite their great wealth and the forces that are promoting increased consumption, those living in Tokyo cannot overcome the biophysical limits posed by increasing depleted marine stocks. These results suggest an urgent need to begin implementing policies that will help lower seafood consumption at the local, national and global level to protect this resource for future generations.
\end{abstract}

Keywords: seafood consumption; Tokyo; ecological footprint.

\section{RESUMO}

Este artigo examina as tendências históricas de consumo de pescado marinho em Tóquio e tensões sobre como promover o consumo urbano sustentável. Apesar das claras evidências de que os estoques de pescado marinho estão se esgotando, o Governo Metropolitano de Tóquio não avançou uma agenda para diretamente dar suporte ao consumo sustentável de pescado marinho. Ainda, apesar destas tendências, os padrões de consumo desde os anos setenta mudaram de maneiras imprevisíveis. A proporção de consumo per capita de pescado marinho de alto de nível trófico, que é valorizada comercialmente e denota alto status, como os peixes carnívoros, está decaindo, enquanto que o consumo de outros tipos de pescado marinho de níveis tróficos mais baixos está crescendo. Adicionalmente, os preços do pescado marinho aparentam ter um papel reduzido na configuração destas tendências. Apesar da grande riqueza

\footnotetext{
" Doutora em Ciências Ambientais Humanas e da Terra pela Universidade de Chiba, Japão. Professora Adjunta, Departamento de Construção Civil, Universidade Tecnológica Federal do Paraná (UTFPR). E-mail: tatianagadda@utfpr.edu.br

"* Doutor em Planejamento Urbano pela Universidade de Columbia. Professor Associado, Departamento de Geografia, City University of New York (CUNY).

E-mail: Peter.Marcotullio@hunter.cuny.edu
} 
e das forças que promovem um consumo crescente, os habitantes de Tóquio não podem transpor os limites biofísicos resultantes de estoques de pescado marinho em crescente degradação. Estes resultados sugerem uma necessidade urgente de começar a implantação de políticas que possam ajudar a reduzir o consumo de pescado marinho nos níveis local, nacional e global a fim de proteger este recurso para as gerações futuras.

Palavras-chave: consumo de pescado marinho; Tóquio; pegada ecológica.

\section{Introduction}

An emerging recognition of the impacts of consumption on ecosystems near and far has propelled this issue into a premier position within the overall global objective of sustainable development (CLARK, 2006). As consumption activities are increasingly occurring in cities (UN-HABITAT, 1997), focusing on changing urban consumption patterns is particularly important for policy. Moreover, as the world rapidly urbanizes, it is in the cities of the world that the struggle to obtain sustainable consumption levels will be fought most intensely. Despite these obvious conclusions, however, there are few studies that have examined the details of consumption at the urban level (for important exceptions see, BEST FOOT FORWARD, 2002; FOLKE et al,. 1997; REDEFINING PROGRESS, 2004; SANTA MONICA SUSTAINABLE CITY PROGRAM; REDEFINING PROGRESS, 2004; WARREN-RHODES; KOENIG, 2001) and fewer that explored how they have changed over time.

This article examines the marine seafood consumption trends over 50 years in Tokyo, a high-income city in East Asia. There are several reasons why Tokyo makes a good case study. First, Tokyo is a "global city" known for its international linkages in trade, finance, investments, etc., and high levels of affluence, obtained largely since 1950 (SASSEN, 1991). Understanding changing seafood consumption patterns implicates the association of these trends with both growing wealth and globalization flows. Second, it is also a city well known for its seafood appetite. Citizens of Tokyo, for example, consume more seafood than all of Canada, twice that of the Netherlands, almost three times the consumption of Sweden and 6 times that of Switzerland (GADDA, 2006). Hence, it is arguably a good target for promoting sustainable consumption in this area. Third, the city government has made impressive attempts at promoting policies for sustainable development (FUJITA; HILL, 2007). Given this commitment to sustainable development, it is interesting to examine how the city is addressing seafood consumption.

Through reviewing literature on sustainable consumption, this paper proposes a framework to understand seafood consumption in Tokyo. This is the first attempt to quantitatively identify seafood consumption in this, or any, city. The first section discusses aspects of sustainable food consumption. In the second section, we present an analysis of the patterns of Tokyo's seafood consumption based upon the calculation of the ecological footprint and an analysis of types of seafood consumed over time. The article also examines the different factors have influenced Tokyo's marine seafood consumption patterns. We explore the potential driving forces which include governmental policies and influences from the private sector, changing income and preferences, seafood prices and the carrying capacity of natural resources. In the third section we attempt to account for the trends found in the previous section through reviewing the post-war history of policies related to seafood consumption at both the local and national levels, understanding the changing wealth and protein preferences of citizens of the city, investigating the relationship between price and seafood consumption and examining changes in the global marine environment over the past 50 years. The last section presents our conclusions.

\section{Sustainable seafood consumption: some theo- retical propositions}

A city can be associated with a sustainable pathway when its citizens address a number of different environmental challenges. For example, some important environmental goals include clean and healthy internal 
conditions for citizens, reductions of local and metropolitan wide pollutants and decreases in the consumption of global resources, ecosystem services and associated emissions (McGRANAHAN et al,. 2001; SATTERTHWAITE, 1997). While cities in lower income countries struggle with local brown agenda issues, cities in the global North have already addressed these challenges, by providing environmental infrastructure. These wealthier cities, however, have only partially succeeded in the second task which addresses the environmental issues related to the grey agenda (many are still struggling with regional air and water pollution including acid rain precursors from industry and transport, heat island effects, etc). No city has achieved levels of sustainable reductions in consumption and waste emissions (LEE, 2006). This third aspect is crucial to sustainable development and implicates, among other things, policies for sustainable consumption. Although the concept has only recently reached policy circles, there is a growing body of literature on sustainable consumption (for a review see, JACKSON; MICHAELIS, 2003).

The term "sustainable consumption," coined around the time of the Rio Earth Summit in 1992, has come into popular usage. The common institutional definition of sustainable consumption focuses on consuming differently through the production and sale of more sustainable products (JACKSON; MICHAELIS, 2003). Hence, rather then consuming less, the search for sustainable consumption has focused on production and waste reduction. Newer thinking on consumption, however, suggests that it should be "reasonable" and therefore policies should not always promote more (KRONENBERG, 2007).

Sustainable consumption policies suggest that consuming rationally (i.e., lowering product throughput), consuming less (lowering total material consumption) and consuming differently (satisfying needs in ways that do not directly increase consumption) can be achieved with economic growth. This thinking has emerged as a response to observations that consumerism is pathological (i.e., increasing consumption does not bring increases in human well-being) (KASSER, 2002), mal-adaptive (i.e., consumerism is part of an evolutionary trait that no longer applies to modern society) (RIDLEY, 1994) and often controlled by path-dependence (i.e., consumers are locked-in rather than exhibiting free choice) (SANNE, 2002). As such national policy frameworks on sustainable consumption have been promoted. One of the most encompassing approaches has been introduced by the British (UK SUSTAINABLE DEVELOPMENT COMMISSION, 2009; UK CABINET OFFICE - STATEGY UNIT, 2008a, 2008b). Policies findings suggest that sustainable consumption includes safe, healthy and nutritious food; protecting the livelihoods of farmers, processors and retailers, respecting animal health and welfare, supporting rural economies and respecting biophysical and environmental limits (emphasis added) (UK SUSTAINABLE DEVELOPMENT COMMISSION, 2005).In the arena of primary commodity consumption, respecting biophysical and environmental limits implicate our ability to produce natural resources, such as agricultural products, effectively and with limited environmental impact. When it comes to seafood production and consumption, however, the global human population remains largely engaged in hunting and gathering activities. While aquaculture production is growing, it makes up only a small proportion of total seafood production. Of total global marine seafood production (fish, mollusks and crustaceans) in 2004, approximately 16.4 per cent were from aquaculture production. Of this share, only 7 per cent is from fish aquaculture, while 79 per cent if from mollusk aquaculture production and 14 per cent from crustacean aquaculture production. ${ }^{1}$ Most marine seafood is obtained through fishing of marine seafood stocks.

While there is waste to reduce in fishing practices (particularly in the form of lowering the unwanted catch - bycatch), there has yet to be an effective way to manage fisheries to maintain optimum fish population levels. A recent global assessment of the world's ecosystems and the ability of these ecosystems to produce the goods and services necessary for human well-being suggests that all oceans are affected by humans to various degrees, with overfishing having the most widespread and the

${ }^{1}$ FAO Fishery Information, Data and Statistics Unit (FIDI). c2002- . Fishery Statistical Collections. FIGIS Data Collection. FAO - Rome. Updated Wed Oct 25 10:43:29 CEST 2006. 
dominant direct impact on fish stocks (PAULY; ALDER, 2005). In some areas of the ocean, the biomass of fish has been reduced to one tenth or less of the level that existed prior to the onset of industrial fishing (CHRISTENSEN et al., 2003; MYERS; WORM, 2003).

The responsibility of depleted stocks falls unevenly on different national fisheries. The per capita consumption of seafood in Northern rich countries is far greater than that of the poorer nations. In the latter case, there are also fewer alternative protein sources. Hence, understanding marine seafood consumption patterns, particularly in wealthy nations, can help promote and understanding of equity concerns and support ecological resource conservation. Both aspects are urgently needed given current trends (MILLENNIUM ECOSYSTEM ASSESSMENT, 2005). Moreover, understanding what drives this consumption is important for policy.

We argue that four aspects are central to understand seafood consumption: governmental policies and private sector influence, increasing wealth and consequent changes in preferences and consumption levels, seafood consumption in relation to changes in prices and the carrying capacity of ecosystems to provide services for human well-being. In the next sections we present our theoretical understanding of these factors and what we would expect in the case of Tokyo's marine seafood consumption.

\subsection{Government policies, the private sector and natural resource consumption}

Policy frameworks for resource management within democratic societies place the government in a managerial role. As such, the role of government is to influence consumer behaviour via a number of different measures such as regulations, standards, market instruments, education and planning (CHIRAS; REGANOLD, 2010). Very often, embedded in this thinking is that governments should encourage consumption. This is because increased consumption associates, in the traditional sense, with increased well-being. In this viewpoint, as individual preferences vary, the role of the government is to provide the widest variety of goods for the most people.

Some important national policy measures related to traditional encouragement of consumption for seafood include implementing supporting regulations and incentives for the domestic fisheries industry, regulating the import and export of the fishery products, providing infrastructure (everything from ports to market facilities), using education awareness campaigns and creating standards for food safety. A particularly important benefit from government for primary industries is subsidies, which come in many different policies (MYERS; KENT, 2001).

At the local level, governments have used planning, laws and incentives to encourage consumption. Policies that have affected urban form, for example, have influenced personal travel and energy use (NEWMAN; KENWORTHY, 1999). Decisions to allow or restrict supermarkets have an effect on shopping habits and food choices (SIMMS et al. 2002). At the local level, regulations and support for seafood market infrastructure and planning to enhance the market environment and distribution are important policies that promote seafood consumption. We expect therefore that the Tokyo Metropolitan Government (TMG) has helped to manage seafood consumption through planning, laws, incentives and provision of infrastructure.

The private sector often interacts with the government to enhance consumption. For example, professional lobby organizations work to secure specific benefits from governments, be they infrastructure or protection (even of other industries), which influence their profits. As members of an industrial group, companies promote the consumption of their products. An important avenue in which the private sector helps to increase consumption is through advertising. Motivating human behaviour developed into a science that provides insights into how consumers can be influenced in a number of subtle ways, such as through the use of humour, flattery and provocative associations between products and desires (DICHTER, 1971). We expect therefore that private retailers are involved in promoting seafood consumption in Tokyo through media and lobbying for infrastructure. 


\subsection{Increasing wealth and natural resource consumption}

Changes in wealth and lifestyles are associated with changing patterns of resource consumption. With increasing household wealth, disposable income can purchase new items or greater quantities of items previously purchased in small quantities. It is a widely recognized fact that with increasing wealth material consumption of goods increases and this can be seen, for example, in changes in per capita amounts of municipal solid waste (COINTREAU, 1982); (WORLD BANK, 1992).

A number of factors determine the specific patterns of changing consumption with increasing wealth. For the study of changing food consumption, important influences include substitutability, convenience, status and taste. For example, we would expect that as protein substitutes for seafood become available (including cow, pig, chicken etc), consumers switch a portion of their consumption from fish to meat. At the same time, how convenient it is to purchase these goods, their status in society and the relative taste for the good can work to push trends in either direction.

Another factor that influences the consumption of seafood with increasing wealth is technology. On the one hand, with increasing wealth comes the adoption of advanced technologies, which have the power to both decrease per capita consumption levels through efficiency gains and increase consumption through the introduction of new demand. For example, replacing older, less efficient production technologies can result in gains in terms of more efficient use of material inputs into manufacturing. On the other hand, new technologies for production (factory ships, etc) can increase consumption levels.

Within the fisheries sector, the adoption of new production technologies since the 1950s has helped to expand the reach of the domestic sector (see SWARTZ, 2004 for a detailed spatial study on Japan). This in turn has made a larger number and assortment of seafood available to the Japanese at lower prices. Innovations related to post-war fisheries include an enormous range of electronic devices that started with introduction of radar and acoustic fish finders onboard fishing vessels culminating at the close of the Cold War with the introduction of GPS technology and detailed seabed mapping which enabled fishers to aim for specific small places with high fish abundances, which until then were protected by the depth and vastness of the oceans. Moreover, net technology has changed dramatically allowing for deeper and wider castings. At the same time, globalization flows facilitated the import of a larger amount and variety of imported fish.

We recognize that seafood is a necessity, although specific types of seafood are luxury goods. For example, according to Bestor $(2004$, p. 309) while an ordinary tuna will sell for three to four thousand yen per $\mathrm{kg}$, an extraordinary tuna will sell for 10 to 12 thousand yen per $\mathrm{kg}$ (or approximately US\$9-10,000 for a $100 \mathrm{~kg}$ fish). A tuna was sold in the first auction day of the new millennium for 100 thousand yen per $\mathrm{kg}$ (US\$ 90,000 for a 100 $\mathrm{kg}$ fish)! Notwithstanding these special circumstances, seafood and particularly carnivorous fish, such as tuna and salmon, are highly preferred by the Japanese and arguably important for health. As a necessity, the consumption of seafood should experience a per capita increase but only to a point. Thereafter, decreases in consumption of this commodity might relate to the substitution of this form of protein with that of meat protein, depending upon relative prices, tastes and preferences. At the same time, we would also expect that the high status seafood, such as the high trophic level fish, would increase in share of total seafood consumed with increasing income.

\subsection{Price and natural resource consumption}

Economists typically argue that price is an important factor in influencing consumption. Price theory suggests that as the supply of a particular good decreases, with demand remaining the same, price for that good will rise. Alternatively, as supply increases, prices will fall. Within a group of similar products (i.e. different types of fish), prices will fall and rise differentially, creating a diverse set of prices for consumers from which to pick and choose. Consumers will weigh the benefits of consuming one type of seafood against another in this sea of differential prices. Hence, prices are both an indicator of the relative amounts of a good with respect to its de- 
mand and an influence on consumption (BROWNING; ZUPAN, 1999). It is therefore important in this study to track price changes of goods over time.

Two prices influence the consumption of seafood: the price of the particular fish (A) and the price of close substitutes for that fish (B, C, etc). All else being equal, an increase in the price of the particular species of fish (A) will reduce the consumption of that fish and vice versa. This is known as the own-price elasticity of consumption, defined as a per cent change in the consumption of a particular species of fish (A) brought about by a per cent change in the price of that species (A). A decrease in the price of another species of fish (B), ought to decrease the fish consumption of the species of fish A, if they are substitutes for each other. The relationship between a good and its substitutes is the cross-price elasticity of consumption, defined in this case as the per cent change in the consumption of the fish A produced by the change in price of fish $\mathrm{B}$. A negative cross-price elasticity of consumption means the two goods are complements, and occurs when an increase in the price of say, tuna, results in a decline in consumption of say, squid. A positive cross-price elasticity of consumption implies that the two goods are substitutes and means, for example, that an increase in the price of tuna (a highly prized fish) results in an increase in the consumption of squid (for a similar type of analysis done for bushmeat see ALPAZA et al, 2002). That is, if we find cross-price elasticity between these two types of fish in Tokyo, as the price of tuna increases, people will shift their preference to less prized but relatively cheaper fish.

In order to perform the analysis for all fish sold in the city, we standardized our price data by 1953 levels and compared changes in price over time for over 400 species of fish. We further aggregated fish by trophic levels (see section 3 ) so as to compare the general changes in prices of groups of fish consumed over time (Table 1). Given the theory explained above, we expect that the relative changes in fish price would be reflected in consumption patterns in different types of fish. That is, if for example, carnivorous fish prices rise faster than other species of fish, then carnivorous fish should be purchased relatively in lower amounts than other fish types.

\subsection{Biophysical limitations and resource consumption}

Carrying capacity is the biophysical limits for animal populations. Typically, the carrying capacity of a particular ecosystem equals the number of species that can live within its boundaries. The notion of carrying capacity has been on the policy agenda for decades if not centuries. Originally, the idea that population growth would outstrip human ability to provide food was promoted by Thomas Malthus, writing in the late $18^{\text {th }}$ Century. Subsequently, the notion was revived several times and since WWII there have been three global waves of interest in the theory (LINNER, 2003). Essentially, neo-Malthusian thinking includes the idea that natural resources were being used at unsustainable rates and quantities and that this overshoot would end up in market crash and social chaos (CATTON, 1980).

Humans, however, have continually overcome local constraints by appropriating ecosystem services from outside immediate environments. In the past, each

TABLE 1 - CHANGES IN PRICE INDEX AND FISH CONSUMPTION IN TOKYO BY TROPHIC LEVEL, 1953-2003

\begin{tabular}{lrrrrrrrr}
\hline Fish type & Trophic level & Value & 1953 & 1963 & 1973 & 1983 & 1993 & 2003 \\
\hline Herbivores & 2.1 & price index & 100 & 254 & 851 & 1310 & 1522 & 1410 \\
& & kg/capita & 0.60 & 4.37 & 5.00 & 6.83 & 6.91 & 5.11 \\
& & & & & & & \\
Omnivore & $2.2-2.7$ & price index & 100 & 188 & 439 & 754 & 762 & 613 \\
& & kg/capita & 0.97 & 2.26 & 4.57 & 4.38 & 4.88 & 3.61 \\
& & & & & & & \\
Carnivores & $2.8-4.6$ & price index & 100 & 168 & 428 & 940 & 1022 & 841 \\
& & kg/capita & 30.20 & 42.33 & 43.55 & 40.65 & 37.61 & 27.73 \\
\hline
\end{tabular}


time scientists or policy makers broached concerns over the carrying capacity of ecosystems, new information and technologies facilitated thinking that societies could overcome all biophysical obstacles. Indeed, some advocated that people, not resources were the ultimate limitation (SIMON, 1981). Implications from studies in ecological economics, such as ecological footprint analysis (WACKERNAGEL; REES, 1996), ecology, such as the human appropriation of net primary production (VITOUSEK et al., 1997) and industrial ecology (AYRES; SIMONIS, 1994), however, suggest that we are coming to the end of our ability to appropriate these services. According to one study, we are already appropriating 20 per cent more ecological services than the world can supply on a continual bases (WACKERNAGEL et al., 2002). This means that we are now eating into Earth's stocks, rather than simply consuming the flows.

The latest incarnation of interest in carrying capacity has come from those interested in sustainable consumption (JACKSON; MICHAELIS, 2003). Arguably, this newest attention emerged with recent concerns over post-peak oil, water scarcity and fisheries depletion. Indeed, geographic, species-specific marine resource crashes have already occurred. For example, the Newfoundland cod fisheries crashed in the 1990s and have yet to return. At its peak, this area was producing approximately 800,000 metric tons of fish annually. This crash has helped to produce an overall decline in global cod production from 4.1 million metric tons in 1968 to 1.3 million metric tons annually in 2004 (ANON, 2006).

While scientists and popular media make much over the future exhaustion of resources, most governments do not recognize that current consumption levels have already reached or surpassed levels that the global commons can provide. Governments argue that we have not nearly reached these levels and therefore continue to subsidize fisheries. The total global subsidies to support the $\$ 90$ billion global fishing industry are estimated to be around $\$ 15$ billion (BRADSHER, 2005).

\section{The historical patterns of seafood consumption in Tokyo}

Scientific studies designed to identify how much "nature" humans need in order to survive in our current manner can be divided into, at least, two types: the measures of human appropriation of net primary production (see for example, VITOUSEK et al., 1997), and measures of a population's Ecological Footprint (EF) (REES; WACKERNAGEL, 1996; WACKERNAGEL; REES, 1996). ${ }^{2}$ The EF is "the area of biologically productive land and water required to produce the resources consumed and to assimilate the wastes generated by that population using prevailing technology" (WACKERNAGEL; REES, 1996). One can think of the EF as the sum up of specific real locations, the "distant elsewhere" that support us (REES, 2002).

We use the concept of EF to measure marine seafood consumption over time. To calculate marine seafood ecological footprints, we adopted a formula developed by Wada (1999) after Pauly and Christensen (1995), as shown below.

$$
\begin{gathered}
\text { Seafood EF }=\left\{(\text { Total Supply }+ \text { Bycatch }) / 9 * 10^{\mathrm{TL}-1}\right\} / \\
\text { Primary Productivity of the area }
\end{gathered}
$$

Total Supply includes the sum of "real wholesale supply" and "retail supply" of seafood for Tokyo in tons of live fish. Bycatch, or discard, added to the Total Supply results in the Total Appropriation of Seafood or Total Consumption of Seafood by Tokyo. The figures used for discarded bycatch correspond to a volume of catch per ecosystem (ALVERSON et al., 1994). In our calculations, however, we used seafood supply instead of catch and converted Total Supply into tons of live fish weight using Japanese conversion rates whenever possible. We assumed the rate of Bycatch for individual species to be constant during the study period.

The Total Consumption of Seafood by Tokyo is then divided by nine to convert wet weight into tons of carbon (tC) (PAULY; CHRISTENSEN, 1995; STRATH-

${ }^{2}$ For a comparison of these two types see Haberl et al. 2004. 
MANN, 1967; WADA, 1999). We then multiplied the carbon value for each fish species by $10^{\mathrm{TL}-1}$. This is because biomass energy transfers up the food web with efficiencies between five and 20 per cent moving up trophic levels (TL). A widely accepted mean is 10 per cent energy transfer efficiency. This implies that an organism in a given tropic level (hierarchical niche within the food web), on average, incorporates 10 times more primary production than does one with the same mass in the tropic level immediately below (WADA, 1999). Finally, the entire value is divided by the primary productivity of the marine area (also in tons carbon $-\mathrm{tC}$ ). The final values are the Seafood Ecological Footprint in hectares. We calculate the total marine seafood EF and the per capita EF by adding up the individual EFs for over 400 species for each year within our database (see Figure 1).

We also calculate changes in the mean trophic level of fish consumed. As mentioned, trophic levels relate to hierarchical niches within the marine food chain. Lower TLs imply positions closer to the primary producers and higher TLs imply carnivores on top of the web. Most species of fish consumed fall between a TL from 2.1 to 4.6 according to its position within the food chain. Herbivores locate at a TL between 2.0 and 2.19, omnivores'
TLs range from 2.2 and 2.79 and the TLs of carnivores are equal to or greater than 2.8 (PALOMARES, 2000). ${ }^{3}$ Pauly et al. (1998) analyzed the diet of 220 species of fish and shellfish to assign each species a TL. Using these data, available on the internet (see: $<$ www.seaaroundus. org $>$ ), we calculate volume and average annual TL for the species consumed in Tokyo from 1953 to 2003 of each seafood species consumed in the city. We used the mean trophic level of species consumed in Tokyo as another indicator of (un)-sustainable seafood consumption. Table 2 presents the data summary of calculations for each decade. As demonstrated in Figure 1, in 1953, the marine seafood EF per capita for Tokyo was approximately 0.6 hectares per capita. This level, for the total population eating in Tokyo (approximately 4.5 million), was under that of the Tokyo's region (i.e., Tokyo Bay and environs ${ }^{4}$ ) ability to supply seafood. Hence, the ratio of marine seafood EF to biocapacity was under 1.0. From 1953 to 1963 , however, the population eating within the city increased by over 50 per cent and the amount of seafood appropriated increased by over 150 per cent. The marine seafood EF per capita jumped to 1.21 hectares and the city entered the state of "overshoot." That is, it was consuming more than its local area could produce.

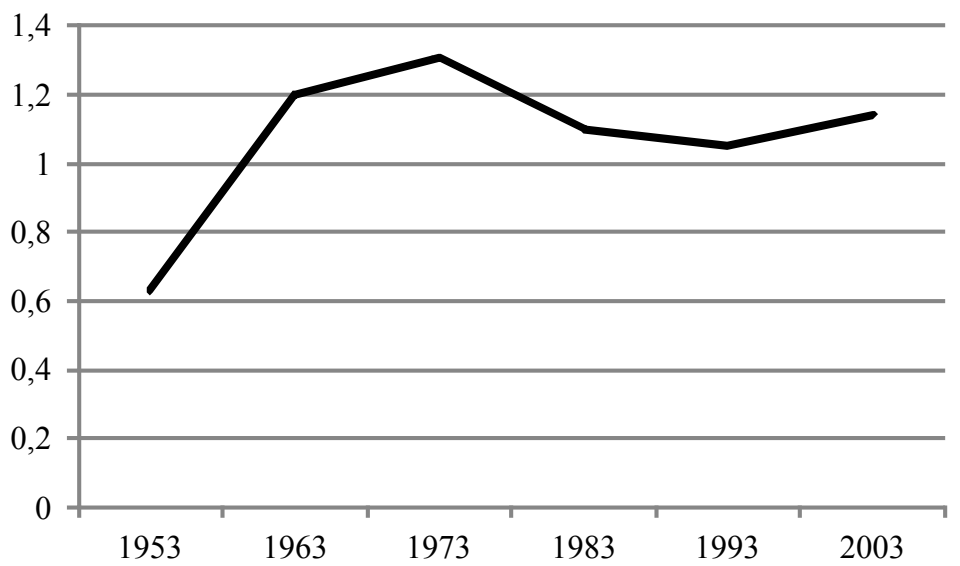

FIGURE 1 - Tokyo's changing seafood Ecological Footprint (ha/per capita/year).

\footnotetext{
${ }^{3}$ Top predators (such as tuna, billfish and shark) have a trophic level equal to or above 3.75 .

${ }^{4}$ Regarding the area used in terms of marine surface area that could sustainably support Tokyo resident's consumption, we arbitrary used the amount of marine area controlled by the city. In this case we use the size of Tokyo Bay and the EEZ around the Tokyo Islands. The share of EEZ that includes Tokyo Bay and area surrounding Tokyo islands are approximately 38 per cent of Japan's EEZ. Japan's EEZ, in turn, ranks the sixth largest in the world and is about 12 times the size of its land area. Additionally, the sea areas of Tokyo have, on average, a higher PP than the global mean. For these reasons we believe our calculations are still conservative.
} 
GADDA, T, M. C.; MARCOTULLIO, P. J. Changes in Marine Seafood Consumption in Tokyo, Japan

TABLE 2 - ANNUAL CHANGES IN TOKYO'S TOTAL SEAFOOD SUPPLY, BYCATCH, TOTAL AND PER CAPITA CONSUMPTION, EF, AVERAGE TL AND SEAFOOD ECOLOGICAL DEFICIT, 1953-2003

\begin{tabular}{|c|c|c|c|c|c|c|}
\hline & 1953 & 1963 & 1973 & 1983 & 1993 & 2003 \\
\hline Total Supply (tons live fish) & 225,285 & 599,656 & 840,492 & 845,857 & 872,520 & 868,497 \\
\hline (percent wholesale) & 100 & 83 & 68 & 69 & 63 & 41 \\
\hline (percent retail) & 0 & 17 & 32 & 31 & 37 & 59 \\
\hline Bycatch (tons live fish) & 66,165 & 171,985 & 243,299 & 248,244 & 258,380 & 254,665 \\
\hline Total Appropriation (tons live fish) & 291,450 & 771,641 & $1,083,791$ & $1,094,100$ & $1,130,900$ & $1,123,163$ \\
\hline Tokyo’s real GDP per capita (US\$)* & $2,130^{\S}$ & 3,475 & 8,382 & 20,031 & 57,082 & $54,165^{\Omega}$ \\
\hline $\begin{array}{l}\text { Tokyo's per capita consumption of } \\
\text { seafood }(\mathrm{kg} / \text { person }) * *\end{array}$ & 34 & 58 & 70 & 69 & 69 & 66 \\
\hline (percentage carnivores) & 95 & 86 & 82 & 78 & 75 & 76 \\
\hline (percentage omnivores) & 3 & 5 & 9 & 8 & 12 & 10 \\
\hline (percentage herbivores) & 2 & 9 & 9 & 13 & 14 & 14 \\
\hline
\end{tabular}

NOTES:

"From 1955 to 1974 the base year is 1980 . From 1975 to 1989 the base year is 1990 . From 1990 to 2002 the base year is 1995 .

$\S$ This figure refers to the first year available for GDP, 1955.

$\Omega$ This figure refers to the last year available for GPD, 2002.

'We calculated Tokyo's population based on how many people eats in Tokyo daily. Therefore, night-time and daytime population follows the formula: [(night-time population $* 2 / 3)+($ daytime population $* 1 / 3)]$. The data from night-time population is based on TMG statistic on population (from $1^{\text {st }}$ October of each year). Daytime population is based on the national census conducted every five years (from $1^{\text {st }}$ October of each year).

"* It includes the trophic level 2,0 assigned to the species which TL could not be obtained.

*** The per capita Seafood Ecological Deficit of Tokyo is the difference between Tokyo's EF per capita and Tokyo's marine biocapacity per capita.

Appropriation of services outside its local area continued to increase over the next decades as total population increased by 15 per cent and total supply of seafood increased by approximately 40 per cent. The result was that the marine seafood EF of the city reached its highest level of 1.31 hectares per capita. The city was appropriating over 30 per cent more than the marine area around Tokyo could supply.

The next two decades saw a drop in marine seafood EF per capita of the city, as population increased faster than total marine seafood supply. With this drop came an EF level close to that of what the Tokyo marine area could provide. During the most recent decade, however, while population growth has slowed and total supply has decreased the marine seafood EF of the city increased.
This was due to the slight increase in average trophic level of the fish consumed in the city.

Figure 2 presents the trend in average TLs. It demonstrates that while citizens consumed species at the higher TL, such as tuna, in abundance lower trophic species have been increasingly more prevalent on Tokyoites' plates. The mean TL of seafood appropriated by Tokyo decreased steadily from 3.40 in 1953 to 3.19 in 1993. During the last decade the mean TL grew 2 per cent, reaching an average TL of 3.24.

We identified the main fish groups responsible for the downward trend as well as the reason for a TL increase in the last decade. An aggregation of TLs for species with similar functional niches (herbivores $=\mathrm{TL}$ 2.1 , omnivores $=$ TLs from 2.2 to 2.7 , carnivores $=$ TLs 


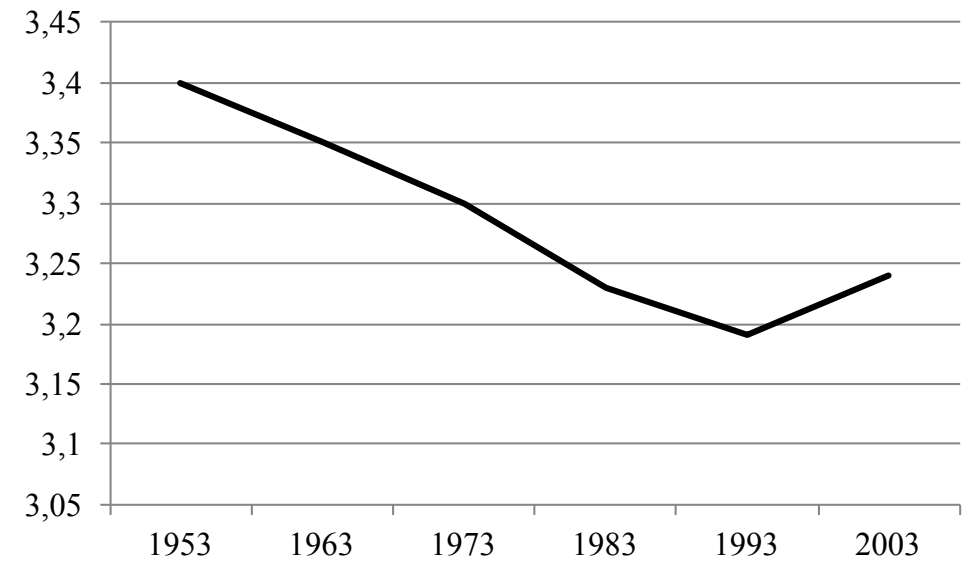

FIGURE 2 - Average trophic level of Total Supply (mean trophic level/year).

from 2.8 to 4.6 ) demonstrates that the proportion of carnivores appropriated by the city has been decreasing. For example, by volume carnivores represented 95 per cent of the total volume in 1953 . Thereafter its share decreased steadily till 1993 to 74 per cent of total volume consumed, but increased slightly to 76 per cent during the last decade. On the other hand, the appropriated volume of herbivores and omnivores increased from 1953 to 1993. Between 1993 and 2003 the share of herbivores out of the total seafood consumed in Tokyo stabilized at 14 per cent while omnivore's share declined from 12 to 10 per cent. ${ }^{5}$

The question remains as to what influenced these trends. In order to explore this question, we turn to the history of seafood consumption, in regards to government fisheries policies and private sector activities, changes in affluence, changes in seafood prices, and trends in oceanic seafood service capabilities.

\section{Factors Underlying the Historical Trend}

In this section we review the history of the four factors affecting natural resource consumption presented in the theoretical section and focus specifically on the seafood consumption in Tokyo. This analysis suggests that government policies, private sector activities and increasing wealth are not good indicators of trends in Tokyo's marine seafood footprint. Moreover, the price of fish was also not a good indicator of shifts in consumption pattern changes. The strongest influence on the patterns of marine seafood consumption is global overfishing, or over-exploitation of this resource.

\subsection{Japanese governmental policies and private sector activities related to seafood consumption}

There are both local and national policies that affect seafood consumption. At the local level, the Tokyo Metropolitan Government (TMG) has largely supported and encouraged the development of city's seafood markets. The TMG assures the delivery of fresh foods to the market, consumer safety and reasonable prices. This is accomplished through the Wholesale Market Law and Ordinances that provide direction and supervising the handling of fish, the construction of markets, and their maintenance and management.

\footnotetext{
${ }^{5}$ Within the omnivores all trophic level groups experienced an increase in the volume consumed per capita from 1953 to 1993 followed by a decline in the last decade. The exception is the trophic level 2.6 that declined earlier (from 1973 to 1983) driven by decline in the consumption of Konoshiro gizzard shad (Konosirus punctatus) - a species which population from Tokyo Bay have recently been found to be suffering from endocrine disruption.
} 
A prominent seafood market, located in Tsukiji, east of Ginza at the mouth of the Sumida River, is the world's largest. Officially called the Central Produce Market, because more than fish is sold there, Tsukiji market has a long history. Together, Tsukiji and two other smaller markets, Adachi and Ota, ${ }^{6}$ (opened in 1945 and 1989 , respectively) account for all the wholesale seafood sold within the city.

The dominance of wholesale markets began to decline during the 1970s but remained stable until the end of the 1990s. In the decade ending in April 2002, the amount of seafood being traded through wholesale markets declined by a fifth. By 2003, approximately 59 per cent of the seafood consumed in the city was purchased through retail centers. This is largely because retail outlets have increased in number and importance and are able to buy direct from producers.

At the same time, however, throughout the period TMG remained committed to keeping the Central Market operational, as the market is home to 15,000 jobs and does approximately 2.4 billion yen in daily business. This translates into moving approximately 700,000 metric tons of seafood annually. The TMG, now has plans to upgrade Tsukiji's facilities by selling the land and moving the market around Tokyo Bay to the Toyosu Wharf in Koto Ward by 2015. The new location will have better facilities and more space for trucks to load and unload their fish, meat and vegetables. Traders will also have bigger stalls to display their fish and will be able to install additional refrigeration and processing equipment to keep the fish fresh.

One might expect the TMG to experiment with sustainable consumption policies for fish as it has demonstrated progressive policies in other environmental areas. For example, some new policies focus on reducing energy consumption through the creation of an eco-market-base society using cooperative dispatching to cut down on transportation cost and eco-labelling to inform consumers of product ratings, production location and energy saving potentials. The TMG is also engaged in a number of other exercises to lower waste, combat global warming and promote recycling (FUJITA; HILL, 2007). None of these policies, however, focus on seafood consumption.

In this vacuum, national policies have been a more formable influence on consumer behaviour. The national government has a long history of encouraging consumption. In the arena of fisheries, the national government has consistently promoted consumption as part of economic development. Recently, the government has turned to health and cultural identity as reasons for keeping seafood consumption high.

In the early period after WWII, after regaining sovereignty in 1952, the Japanese government lifted post-war restrictions on fishing imposed by General McArthur (BESTOR, 2004). In 1954, the Self-Defense Law established a 150,000-man force, and therefore a coastguard, which facilitated exports and imports. The first National Five-Year Economic Plan of 1955 proposed an annual growth rate of 5 per cent, through the promotion of industrial development and foreign trade. In 1960, Prime Minister Hayato Ikeda instituted the Ten-Year Income Doubling Plan that aimed at 9.1 per cent annual growth and proposed the quadrupling of annual production levels. In 1961, the Japanese government abolished the import quotas applied directly after the war for most fish products (SWARTZ, 2004).

The impact of these policies on seafood production and consumption were multi-fold. As the country regained its economy, the primary sector grew, encouraged by the need for more food. The fisheries sector expanded to its greatest levels in early 1960s. During these years the fisheries industry accounted for approximately 1.5 per cent of the nation's employment (over 67,000 workers). In 1963, domestic marine fish catch (excluding whale fishing) grew to 6.2 million tons. In the following year, Japan achieved its highest mark in "self-sufficiency" for fish and shellfish: 113 per cent.

While production increased consumption did so at a faster rate. In a little over a decade, the Japanese appe-

\footnotetext{
${ }^{6}$ Adachi market is since its opening (in 1945) exclusive for aquatic products (both marine and freshwater) while Ota handles not only aquatic products (since 1989) but vegetable and fruits (since 1989), and flowers (since 1990).

${ }^{7}$ Self sufficiency of seafood within Japan is defined as the total value of seafood produced domestically divided by the total value of seafood consumed domestically multiplied by 100 (MAFF, various years).
} 
tite for fish surpassed what the country's fisheries could provide. By 1973, Japanese seafood imports exceeded exports (JAPAN MINISTRY OF AGRICULTURE FORESTRY AND FISHERIES, 1978; MATSUDA, 2000).

The fisheries sector, however, continued to increase production. In 1973, Japanese fisheries production topped 10.6 million tons (JAPAN MINISTRY OF AGRICULTURE FORESTRY AND FISHERIES, 1978). In 1983, the fishing industry's harvest (excluding aquaculture and whaling) exceeded 10 million and by 1984 reached a peak of approximately 12 million tons (JAPAN MINISTRY OF AGRICULTURE FORESTRY AND FISHERIES, 1986). This increase was not due to more persons employed in the industry. The number of fisheries employment was around 47,000, a significant drop from the 1960s. The increase in domestic production $^{8}$ was due to increased fishing effort, defined by the number of and size of the fishing fleet. From 1973 to 1983, the number of Japanese fishing boats increased from approximately 300,000 to approximately 400,000 . The total gross tonnage of these vessels increased from 2.6 to 2.8 million (JAPAN MINISTRY OF AGRICULTURE FORESTRY AND FISHERIES, 1981; JAPAN MINISTRY OF AGRICULTURE FORESTRY AND FISHERIES, 1986). During the early to mid-1980s, Japan reached its highest levels of domestic fisheries production.

Thereafter things began to change. By 1989, Japan, which had been the top fishing country for many years slipped to second place, but in terms of world total, its fishery production remained high. In the late 1980s, for example, Japanese production remained between 1012 million tons or over 10 per cent of total world fish catch (JAPAN MINISTRY OF AGRICULTURE FORESTRY AND FISHERIES, 1997). By the early 1990s, fisheries production began to continuously decline. In 1999, Japan's fish catch decreased to 6.6 million tons equivalent to its catch back in 1963. In 2000, the Japanese self-sufficiency ratio for fishes and shellfishes used as food was 53 per cent. By 2002, fisheries production was 5.8 million tons, of which deep seas (large pelagic) fishing accounted for 0.7 million tons. (STATISTICAL RESEARCH TRAINING INSTITUTE, 2006). The domestic fisheries industry sector continued to loose strength as employment in the sector has dropped to only 0.4 per cent of the nation's employed population.

The drop in domestic production reflected a number of changes in the international and domestic situation. First, the change in the 1980s was due to global enforcement of the 200-nautical-mile exclusive economic zones (EEZ) in accordance with the Convention on the Law of the Sea. Thereafter, Japanese fishing boats could no longer ply the waters close to other nations for their fish and the fish catch by larger vessels operating at a distance from the country decreased. ${ }^{9}$ This change caused domestic fishers to increasingly depend upon their own coastal waters for fish (CORTAZZI, 1994). Offshore and coastal fishing catch efforts have meanwhile increased and until recently there had been a significant growth in fish farming. The more intensive fishing efforts, however, have yielded decreasing volumes of fish. The catch of major varieties of fish indicates that harvest of sardines, Alaska Pollack and mackerel have continued to decline. ${ }^{10}$

As total domestic fishery production decreased, imports increased, keeping the consumption of seafood at more than 11 million tons annually (FOREIGN PRESS CENTER JAPAN, 2004). In 1992, Japan imported 4.7 million tons (ASAHI SHIMBUN, 1995). By 2002, imports reached a record of 6.7 million tons, worth 1.76 trillion yen. In the early part of the $21^{\text {st }}$ Century, the fish and shellfish self-sufficiency ratio dropped to approximately 46 per cent. ${ }^{11}$

The government responded in 2000 , by enacting the Basic Fishery Law designed to secure stable supplies of fishery products and to promote the sound development of the fishing industry. The law was supplemented in March 2002, by the Fishery Basic Plan, which sets a target of 65 per cent for the seafood self-sufficiency ratio

\footnotetext{
${ }^{8}$ Japanese production, also referred to here as domestic production, means the catch by fishing boats flying Japanese flags regardless of the geographical area of the catch.

${ }^{9}$ There are however agreements between Japan and other countries that allows Japan to enter their territorial waters to fish.

${ }^{10}$ According to the Japanese Ministry of Agriculture, Forestry and Fisheries (2002a; 2003; 2004), the assessments conducted from 2002 to 2004 on major fishery resources in the waters surrounding Japan revealed low resource levels for half of the species

${ }^{11}$ The self-sufficiency ratio for seaweeds was about 90 per cent in the 60s. By 2002, it was approximately 66 per cent.
} 
by 2012 (FOREIGN PRESS CENTER JAPAN, 2004). Moreover, Japan is the only country maintaining an Import Quota system among major countries (JAPANESE MINISTRY OF AGRICULTURE FORESTRY AND FISHERIES, 2002b).

Subsidies are an important policy used by the Japanese to keep the industry alive and seafood prices of the domestic catch at some degree of competitiveness with those found internationally (DREYFUS, 1998; MYERS AND KENT, 2001). Jonathan Lash (2003), president of World Resources Institute, estimated that Japan was the largest subsidizer of fishing fleets by providing US\$2-3 billion annually to its fishing industry for capital and infrastructure investments, insurance and tax deferrals and credits (see also LARSEN, 2005).

Another government solution to the seafood production and consumption challenges has been the promotion of aquaculture. Currently all of the approximately $225,000 \mathrm{~km}^{2}$ marine area available for aquaculture within Japan's Exclusive Economic Zone (EEZ) has been developed (HONMA, 1993). This form of fishery focuses on the high trophic, high status fish. For example, of the 220 commercially available fish for aquaculture Japan only uses 23 mostly high value carnivorous fish. To support this activity, the government established the National Research Institute of Aquaculture in 1979.

As the fisheries industry is no longer part of the engine of economic development for Japan, the rationale underpinning promotion of seafood consumption has shifted to include Japanese cultural identify and health. Japan has historically attributed an important symbolic value to seafood. Japan coastal waters are among the most productive and diverse fishing grounds in the world (BERGIN; HAWARD 1996; BESTOR, 2004; MATSUDA, 2000). Excavations of shell mounds and discoveries of objects for fish trapping demonstrates that in the Jounan period (10,000-300 B.C.E) inhabitants of the Japanese islands had seafood as an important part of their diet (BESTOR, 2004). In quantitative terms, however, the Japanese consumption of seafood only became significant during recent times, since the 1930s. It was not until the 1950s and 1960s, however, that eating seafood became widespread (BERGIN and HAWARD, 1996). Despite, the relatively recent decreasing importance of fish consumption, the government maintains that eating fish is an essential part of Japanese culture (see, for example, HEAD, 2005; THE ECONOMIST, 2000).

Another rationale for promoting fish consumption is nutritional concerns. The Japanese diet has changed in recent decades, particularly since the 1990s, when it opened up its red meat market to international trade. As red meat is associated with high cholesterol levels, it has been a target of government interest. In an attempt to control meat intake, the Japanese government has been promoting campaigns such as "A meat diet causes high cholesterol and obesity. Return to traditional eating habits with rice and fish". This together with the "slow food movement" is part of the "Food Education" strategy of the government. The main thrust of the program is to promote greater seafood consumption.

In recent years, even at the national level there have been policy efforts to promote sustainable consumption of food. However, these policies, similar to those at the local level, focus on reducing food waste and promoting food safety. The Food Recycling Law, which began in May 2001, encourages food wholesalers, retailers and manufacturers to reduce and recycle food waste (for use as fertilizer or feed). Under this law, all food-related businesses must cut food waste by over 20 per cent by fiscal year 2006. ${ }^{12}$ The national government has also engaged in campaigns encouraging a recycling-based society to control food waste from households, which represent another 7.7 per cent of all food discards. In July 2000, the national government has also implemented mandatory labeling for all fresh food. These labels must include the product name and place of origin. From April 2001, the label law also mandated the inclusion of all processed food, and information on the name of product, expiration date, raw material whether it was a result of genetic modification and storage method. In general, however, these laws have not targeted lowering consumption. Importantly, as inferred by our discussion on subsidies, Japan does not have a price policy that would reflect resource scarcity.

\footnotetext{
${ }^{12}$ See $<$ http://www.env.go.jp/en/lar/wastelaw/10.pdf $>$.
} 
Finally, there is also evidence that the fisheries-related private sector entities have encouraged seafood consumption through media. In 1991, for example, tapes of a song entitled, "Osakana Paradise" (Seafood Paradise) were released to supermarkets and fish shops to promote increased consumption of fish. In 2002, a new, hipper version of the song reached fish shops and instantly became a hit among young adults and children. The new release timed to take advantage of the "mad cow" disease beef scare, was successful in promoting increases in fish consumption at the time.

\subsection{Changing wealth and food preferences in Tokyo}

Japan and Tokyo has experienced dramatic increases in wealth since the 1950s. Directly after World War II, Japan's economic infrastructure had been destroyed and the economic conditions for people around the country were difficult. Nutrition statistics reflect the low levels of consumption. In 1946, for example, the average caloric intake of the Japanese was 1,400 calories a day. The lack of a merchant marine system closed Japan off from export markets and complicated imports of needed materials including seafood.

By the early 1950s, Japan began rebuilding its industrial and commercial machinery. By 1955 total production output surpassed wartime peak levels and by 1956 , the government declared, "the post-war era is over." Rising incomes led to increased spending that further stimulated the domestic market. This period was the time of greatest growth for the country and is often referred to as the "rapid economic growth period."

The result of these changes was increased caloric intake. By the mid-1950s, the Japanese caloric intake had surpassed the levels prior to the war achieving a daily average of 2,100 cal. per capita. By the mid-sixties, the per capita daily caloric value of food supply in Japan reached 2,500 calories (WATANABE, 2005).

During this period, Tokyo was undergoing massive changes. Recovery accompanied a large in-migration to the country's major metropolitan centers (Tokyo, Osaka and Nagoya), which even outpaced the rate of economic growth. The Tokyo Prefecture, after losing population during the war, grew to 8 million in 1955 and to 9.6 million in 1960 (HONJO, 1998). At the same time, the city was also growing economically. Between 1953 and 1963, the GDP per capita in Tokyo increased 63 per cent.

During the late 1960s, given the expansion of production and wealth, living standards began to show for the city's residents. Families began to buy extravagant items such as cameras. Purchases that are more discretionary followed in the seventies: stereos, cassette recorders, colour television sets, cars and room airconditioners. By the mid-seventies, nearly every urban household owned a washing machine, refrigerator, colour television, and vacuum cleaner (ALLINSON, 1997).

From 1974 to 1989, the speed of economic growth changed and so did consumption patterns. Economic adjustments, emanating from the international global system, forced Japan to undertake painful industrial structural changes. The foundations of global commerce that sped development during the 1950s and 1960s eroded in the 1970s, leaving a less stable setting for international trade relations. Among the most crucial fundamental change was the first oil crisis, provoked by the Organization of Petroleum Exporting Countries (OPEC) in 1973. This led, domestically, to higher costs for raw materials, higher energy bills, inflation, consumer anxieties, industrial cutback and, internationally, to a global economic slowdown. The "oil shock" combined with the USA's decision to abandon the gold standard, which signalled a more flexible global system of exchange rates, forced painful economic restructuring within the country (KIDOKORO et al., 2001). As the Japanese yen would rise and fall in value largely in conjunction with balance-of-payments surpluses and deficits, its successful exporting strategies needed to compensate for these changes. National attention focused on the exportation of its premier industries' goods.

Tokyo continued to growth while Osaka and Nagoya lost population. The anomaly of Tokyo's continued population growth can be explained by the concomitant growth of, at first, new techno-economic based industries, and then the rise of the service sector within the city. Tokyo became the center of international business and financing and the nation's largest enterprises (as defined by capital holding of over 5 billion yen). It became also the center of information service and education in Japan. 
The processes of economic re-structuring were enhanced by the globalization of Japan's economic activity and resulted in the ascendance of Tokyo as a premier world city (SASSEN, 1991).

With all these activities, the city was generating a disproportionate amount of wealth within the country. Between 1973 and 1983, Tokyo's GDP per capita grew 139 per cent, faster than the national average. The result was that with approximately 9 per cent of the population, Tokyo Prefecture was generating over 18 per cent of the national GDP. The large volume and concentration of productive energy made Tokyo a powerful consumptive market.

Affluence became visible for many families within the country, but more so for those in Tokyo. The average monthly income of urban workers' households increased more than 16 times between 1955 and 1989. Discretionary income facilitated changes in food purchases, which differed in significant ways from a generation before. The consumption of rice and sugar dropped off, quite significantly in the case of rice. In contrast, people consumed more meat, fruit, milk and dairy products. The most pronounced shift in dietary preferences was between generations. Older people continued with a diet based heavily on rice, vegetables, and fish. Younger people reduced the consumption of rice and increased protein intake by eating more meat and dairy products. The result was that adolescents in 1989 were on average four inches taller than earlier generations (ALLINSON, 1997).

With increasing wealth, families also began to change food-purchasing practices and in particular eat out at restaurants. Restaurant dinning in the 1950s and 1960s was a luxury saved for holidays or special occasions. During the 1970s, many families went out to dinner once or even twice a week (ALLINSON, 1997).

At the end of the previous period, in the late 1980s, a real estate "bubble" that centred on the country's cities and largely in Tokyo burst sending economic repercussions to other sectors. The country descended into a recession, which would last for over a decade. The recession forced domestic changes. For the next decade, growth slowed dramatically and a host of problems surfaced. The long bust of the 1990s sapped the buoyant confidence of the country that was evident during the 1980s. Economic growth, even in the city of Tokyo stagnated.
During the turn of the $21^{\text {st }}$ Century the country and city slowly pulled out of recession. Economic development of Tokyo has returned and construction projects, large and small have re-emerged in several sections of the city. In 2006, the Bank of Japan, stated that the country's output gap, between what the economy can produce and what it is actually producing, is at long last closed. Optimistic economic forecasts, however, are tempered by the uneven regional enjoyment of recovery within the country. Despite large parts of Honshu that have not had more economic development, job prospects remain bright for the Tokyo area (THE ECONOMIST, 2006). Currently, Tokyo's GDP per capita is approximately US $\$ 81,800$, which is the highest among the world's top 35 global cities (INSTITUTE FOR URBAN STRATEGIES, 2012).

\subsection{Changing relative prices of seafood and consumption}

To examine the relationship between price and seafood consumption we performed an analysis of fish consumed by type (herbivore, omnivore and carnivore) over specific periods of time for both own and cross-consumption relationships. In these analyses we examined the relative change in the amount of seafood consumed of each of these types of fish per change in price for each type of fish. Table 3 presents the results.

For own-fish relationships, the data suggest that during most of the period 1953-2003, fish price correlated positively with fish consumption in each category. That is, over the period, as the price of fish increased so did consumption levels. Specifically, for herbivorous fish, from 1953 to 1973 for very per cent increase in price, there was a 0.97 per cent increase in $\mathrm{kg} /$ capita consumed. From 1973 to 1993, the ratio for this relationship was for every per cent increase in price there was a 0.49 per cent increase in seafood consumption. This can be seen for most fish types for almost all periods.

There is one exception to this trend and that was for carnivorous fish consumption during the period 19731993. For that period, for every per cent increase in price of carnivorous fish there was a decrease in carnivorous seafood consumption of $0.10 \mathrm{~kg}$ per capita. 
TABLE 3 - RELATIVE CHANGES IN CONSUMPTION BY CHANGE IN PRICES AMONGST DIFFERENT TYPES OF FISH

\begin{tabular}{|c|c|c|c|}
\hline \multicolumn{4}{|c|}{ Changes in consumption by change in price, $1953-1973$} \\
\hline \multirow[b]{2}{*}{ Price } & \multicolumn{3}{|c|}{ Amount consumed (kg/capita) } \\
\hline & Herbivorous & Omnivorous & Carnivores \\
\hline Price of herbivorous & 0.97 & 0.49 & 0.06 \\
\hline Price of omnivorous & 2.15 & 1.10 & 0.13 \\
\hline Price of carnivorous & 2.21 & 1.13 & 0.13 \\
\hline \multicolumn{4}{|c|}{ Change in consumption by change in price, $1973-1993$} \\
\hline & \multicolumn{3}{|c|}{ Amount consumed (kg/capita) } \\
\hline Price & Herbivorous & Omnivorous & Carnivores \\
\hline Price of herbivorous & 0.49 & 0.36 & -0.17 \\
\hline Price of omnivorous & 0.52 & 0.39 & -0.19 \\
\hline Price of carnivorous & 0.28 & 0.21 & -0.10 \\
\hline \multicolumn{4}{|c|}{ Change in consumption by change in price, $1993-2003$} \\
\hline & \multicolumn{3}{|c|}{ Amount consumed (kg/capita) } \\
\hline Price & Herbivorous & Omnivorous & Carnivores \\
\hline Price of herbivorous & 3.54 & 5.26 & 3.57 \\
\hline Price of omnivorous & 1.33 & 1.98 & 1.34 \\
\hline Price of carnivorous & 1.47 & 2.19 & 1.49 \\
\hline
\end{tabular}

For cross-fish relationships, we also find that for most periods for most fish types, the relationships between price and consumption are positive. During the 1953-1973 and 1993-2002 periods, a per cent price change in one fish category affected the consumption of fish in another category in the same direction. For example, during the 1953-1973 period, a per cent price increase in omnivorous fish corresponded to an increase in herbivorous fish of $2.15 \mathrm{~kg}$ per capita. During the 1973-1993 period however, the cross-category elasticity relationships changed for carnivorous fish. During this period, carnivores fish consumption reached a peak per capita and thereafter declined. Starting in 1973, an increase in per cent price changes in herbivorous and omnivorous fish corresponded to decreases in carnivorous fish consumption in the order of 0.17 and $0.19 \mathrm{~kg}$ per capita, respectively. That is with increasing prices in other categories, people were buying less carnivorous fish. What is further interesting about this relationship is that the changing prices of carnivorous fish did not have an impact on consumption of other fish types. Therefore this cross-species relationship is probably a function of the decrease in carnivorous fish consumption in general, rather than any structural relationship between prices in other categories and carnivore intake. Furthermore, during the 1993-2003 period, the own species-price and cross-species price consumption relationships returned to what they had been before 1973, except that during this period, prices were decreasing and so were consumption levels in all categories.

It seems implausible that increases in prices of the lower level TL fish lead to lower consumption of higher TL fish. On the other hand, it is plausible that the reduced levels of consumption of higher-level carnivorous fish, in general, have lowered the EF. This period corresponds to a negative trend in the growth of the marine seafood footprint. In other words, during this period the consumption of lower amounts of higher trophic fish may have helped to reduce the marine footprint. At the same time, however, the mean trophic level for fish consumed had been dropping since the 1953s. This is due to a relative increase in consumption of lower level fish throughout the entire time period from 1953-1993, along with the decreases in total fish consumption across categories thereafter, notwithstanding the price - consumption relationships among these fish types.

This analysis leads us to some degree of skepticism over the importance of price in influencing seafood 
consumption levels of different fish in Tokyo during this period. Indeed, the increases in prices of fish are tracking the levels of increased consumption rather than working to change them. Yet, if policies, preferences and prices are not influencing consumption, what could be? We explore the most plausible influence in the next section.

\subsection{Limits to global marine fish stocks}

Global marine ecosystems are under threat of degradation through coastal pollution and overfishing (PAULY and ALDER, 2005). The Living Planet Index for 267 species of marine mammal, bird, reptile and fish species declined by 30 per cent between 1970 and 2000 (LOH, 2004, p. 309). Global fishery catches from marine ecosystems peaked in the late 1980s and are now declining despite increasing fishing effort (MILLENNIUM ECOSYSTEM ASSESSMENT, 2005). Recent estimations suggest that approximately 9 per cent of ocean fisheries are depleted, 18 per cent over-fished and 47 per cent fully fished, leaving only 21 per cent of world stocks moderately fished and 4 per cent underexploited (SCHIERMEIER, 2002).

In 2000, the global wild fish catch was 96 million tons, but fell to 90 million tons in $2003 .{ }^{13}$ The catch per person dropped from an average of $17 \mathrm{~kg}$ in the late $1980 \mathrm{~s}$ to $14 \mathrm{~kg}$ in 2003, the lowest figure since 1965. As fishing fleets have expanded since the 1980s and harvesting technologies improved, they have been able to go after fish at greater depths and in more remote waters. Despite increasing efforts catches of many popular food fish such as cod, tuna, flounder and hake have halved (LARSEN, 2005).

Within East Asia, total fish catch is the largest of the world. In the region, the peak catch occurred in the second part of the 1980s, largely due to high catches of sardine and Alaskan Pollack. Populations of both species, however, continue to decline. At present, virtually all of the major commercially valuable pelagic fish stocks, including walleye Pollack, sardine, Pacific cod, yellow croaker and Japanese jack mackerel, are either fully exploited or depleted (FU et al., 2002).

The decline and degradation of fish stocks are due to a number of trends. Importantly, fishing pressure in some marine systems has reduced the biomass of fish (of both targeted species, especially larger fishes, and those caught incidentally and usually discarded - the bycatch) by one or more orders of magnitudes relative to levels prior to the onset of industrial fishing (PAULY; ALDER, 2005).

Long-term extrapolation attempts of present trends do not bode well for marine stocks. Scientists suggest that fisheries will continue to expand into deeper waters, with serious impacts on biodiversity and decline global catches (PAULY et al., 2003). A recent study suggests that given these trends we can expect all global fisheries to collapse, falling to 10 per cent of the peak production, by around 2048 (WORM et al., 2006)!

The collapse of marine seafood stocks threatens the food source of people around the world. More than a billion people rely on fish as their main or sole source of animal protein (PAULY; ALDER, 2005). This is particularly true in Asia, as 27.7 per cent of total animal protein derives from fish products. While seafood is especially important for satisfying basic nutritional requirements in developing countries, demand is also strong in developed countries and particularly within cities. Folke et al. (1997), for example, calculated that 20 per cent of the global human population living in 744 cities appropriate 20 per cent of the globally available marine seafood supplied. Managing these resources is therefore of vital importance.

Japan's role in direct and indirect fisheries capture is great. "Food mileage" is one measure that describes the geographic extension of Japanese reach for nutrition. The "food mile" indicates the distance food is transported from production to consumption. The Policy Research Institute of the Ministry of Agriculture, Forestry and Fisheries, for example, has conducted research on the Japanese "food mileage."14 By 2001, Japan's mileage value for imported food was 900 billion ton-km (almost

\footnotetext{
${ }^{13}$ Other estimates compensate for over accounting of harvests on the part of some countries. For example, Watson and Pauly (2001) and Hilborn et al. (2003) estimate that the post-World War II rapid expansion of fishing continued until the 1980s with global landings peaking at 80 million tonnes and since then they have declined. ${ }^{14}$ See $<$ http://www.sustainweb.org/chain_fm_index.asp $>$.
} 
1.6 times the total domestic freightage and more than 3 times bigger than the food mileage of South Korea and the United States). ${ }^{15}$ The indicator suggests the effort in obtaining food sources, including fish, from around the world.

Japan remains one of the main fishing nations of the world and has a stake in continuing to produce high levels of fish and to import what it cannot produce. By the turn of the century, Japanese fishing efforts had tripled since the 1980s, and her boats plied waters in almost every ocean (SWARTZ, 2004). There is little else the country can do to immediately secure seafood for its population.

\subsection{Synthesis}

Of the various influences on seafood consumption described, we argue that all have explanatory power in determining seafood consumption patterns in Tokyo. The argument suggests that the economic growth of Tokyo was most rapid in between the 1950s and 1970s. Wealth continued to accumulate through the 1970s and 1980s, but stalled during the 1990s. Between 1993 and 2003, the city recorded negative growth of 0.5 per cent for the decade. Neither the EF nor the TL analyses, however, follow this pattern. One might expect that with increasing wealth, the size of the footprint would grow, based upon both increased consumption of seafood and increased ability to purchase the higher value fish (such as Tuna, Salmon, etc.). ${ }^{16}$ The EF for the city, decreased from 1973 to 1983 , a period of economic expansion. It decreased again from 1983 to 1993, while the total GDP of the city increased. Finally, during the period 1993 to 2003, while the city experienced economic stagnation, if not slight decline in growth, the EF increased slightly. Economic growth in the early decades was partly responsible for the changes in seafood consumption, but thereafter, other factors played a more significant role in defining the city's marine seafood EF.
The descriptive history above emphasizes, however, that until recently, there were no local policies aimed at limiting seafood consumption. If anything, the city did what it could to promote the seafood markets. Rather the responsibility for influencing seafood consumption fell to the Ministry of Agriculture, Forestry and Fisheries. The Ministry has largely been interested in maintaining the self-sufficiency ratio, and in enhancing domestic production. While it was able to achieve this in the 1960s and early 1970s, domestic production dropped slowly thereafter until the 1990s, and precipitously after that. This change relates more to international agreements and the closing of offshore fishing waters in the late 1970s. With fewer coastal waters to fish in, increased Japanese fishing efforts and massive subsidies brought in less and less fish. Market demand focused on imports.

No doubt, the change in preference from fish to red meat plays a role in the EF trends. Over the past decades the total amount of meat (pork, beef and chicken) has increased. For example, in 1960 livestock products made up only 8 per cent of Japanese per capita daily intake of protein. By 2001, the share of livestock intake of protein rose to 32 per cent (GADDA, 2006). ${ }^{17}$ From a high in 1973 of $54 \mathrm{~kg}$ per capita, the average consumption of seafood within Tokyo dropped to $37 \mathrm{~kg}$ per capita in 2003. While increased wealth provides an opportunity for Tokyo's citizens to increase their total protein intake with fish, they choose to do so with other animal sources. Certainly, the educational programs and private sector efforts that emphasize the important connection between Japanese culture and sushi or that emphasize the health risks in meat consumption do not seem to be working.

There is no reason to believe, however, that the reduction in volume of fish per capita, as other animal meat consumption increases, should also accompany a change in the composition of seafood consumed. As demonstrated, the changes in seafood types consumed began in the $1970 \mathrm{~s}$, before the large-scale introduction of other sources of protein, before the changes in

\footnotetext{
${ }^{15}$ See <http:/www.primaff.affrc.go.jp/en/publications/primaff-an-re/annual2003/an2003-9-1.pdf>.

${ }^{16}$ We also note that not all "high value" fish are high TL niche fish. For example, sea urchins and bream are lower lever TL inhabitants. Higher TL fish, however, are known to tickle the palette of Tokyoites and are highly desirable.

${ }^{17}$ Despite diversification of the Japanese diet, accompanied by increasing of meat consumption, to this day fish intake remains significant, providing over 40 per cent of the average Japanese daily animal protein intake. Indeed, between 1960 and 2001, the greatest loss in share of protein source within the Japanese diet is from grains (JAPANESE MINISTRY OF AGRICULTURE FORESTRY AND FISHERIES, 2004).
} 
international law prohibiting fishing within a 200 mile border around other countries and before the changes in the value of the yen to the US dollar and therefore to changes in domestic to import seafood and other animal meat consumption.

To some extent the prices of seafood had some role in this trend, as the price of carnivorous fish was increasing and this led to the increase consumption of other types of fish within the city. What is also interesting, however, is that the relative price of lower tophic level fish (herbivores) increased more rapidly than that of the higher trophic level fish. At the same time, the percentage of herbivores in the average Tokyoite's diet progressive increased. The changing pattern of seafood consumption in this study demonstrates a decreasing trophic level trend over the last 50 years. That is, the average share of lower level seafood species has increased on the plates of citizens, while that of carnivores has decreased. This trend continued despite the rise and fall of relative prices of different seafood types.

One cannot ignore the correlation between the decline in average TL of seafood consumption in Tokyo with global fisheries trends. This seems to be the most consistent indicator of the trends in Tokyo's seafood consumption. The post World War II rapid expansion of fishing fleets throughout the world has led to an increase in the volume of fish landed. At the same time, however, global fisheries have been "fishing down the food web" (PAULY et al., 1998). And citizens of Tokyo have also been "eating down the food web." That is, the changing patterns of consumption within seafood types relate more to the availability of marine fish stocks then to rising incomes, changes in price, changing preferences or government policies.

\section{Conclusion}

The article examines the patterns of seafood consumption in Tokyo and the influences on its changing marine seafood footprint. While there have been discus- sions of urban consumption patterns, there has been a lack of quantification of these patterns and even more rarely have the impact of these consumption patterns been studied over time. Our analysis demonstrates that seafood consumption in the city is not sustainable. That is, the consumption trends, while stable in per capita volume for the last decades, also demonstrate a decrease in average trophic level. Those in Tokyo are eating down the food web, as the world "fishes down the food web." This trend suggests that the marine seafood consumption in Tokyo is currently not sustainable.

Although recent local and national policies to reduce seafood waste are encouraging, we see little institutionalized incentives to control either supply or demand and little to no pressure from civil society to make fishing and trade in fisheries more sustainable. Aquaculture has limited appeal for several reasons. To produce these fish requires fishmeal, which the carnivores eat. Hence, growing these fish may actually increase fish demand, through the increasing need to feed them. The total output of Japan's current aquaculture program available for people is between 0.3-0.5 million tons annually. ${ }^{18}$ This amount will only satisfy, at best, 57 per cent of Tokyo's 2003 demand. Given these issues, the chemical inputs needed for aquaculture, the habitat destruction that accompanies developing fish farms and the threat of disease transfer from farmed to wild breeds, the program has limited future appeal in servicing the country's fish consumption demands.

Finally, we do not mean to suggest that citizens of Tokyo are the only ones responsible for these trends; far from it. Studies of consumption patterns in other cities highlight high levels of seafood consumption also (see for example, FOLKE et al., 1997). Tokyo's trends in seafood consumption are only a forewarning. What is surprising is that despite its great wealth, it cannot avoid the influence of falling fish stocks. Most people in Tokyo would prefer high trophic level fish, such as tuna and salmon, but they are increasingly eating lower trophic level items. All urban seafood patterns may either already be following the pattern set by the city or be soon

\footnotetext{
${ }^{18}$ Total output is approximately 1.25 to 1.35 million tons, which is less than 10 per cent of the country's demand.
} 
to experience the same fate. The question of whether a crash in the global commons of seafood stocks will occur seems to have transformed to the question of when it will occur. The answer may be sooner than we think (WORM et al., 2006).

\section{References}

ALLINSON, G. D. Japan's postwar history. New York: Cornell University Press, 1997.

ALVERSON D. L.; FREEBERG M. K.; MURAWSKI S. A.; POPE J. G. A global assessment of fisheries bycatch and discards. UN FAO Fish. Tech. Paper 339, 1994.

ANON Marketplace Competition: Farmed Cod. In: ALASKA SEAFOOD MARKETING INSTITUTE. Seafood Market Bulletin, 2006.

ASAHI SHIMBUN. Japan Almanac. Tokyo: Asahi Shimbun, 1995.

AYRES, R. U; SIMONIS U. E. Industrial Metabolism: Restructuring for Sustainable Development. Tokyo, Japan: UNU Press, 1994. 285 p.

BERGIN A.; HAWARD, M. Japan's Tuna Fishing Industry: A Setting Sun or New Dawn? Commack, New York: Nova Science Publishers, 1996.

BEST FOOT FORWARD. City Limits - a resource flow and ecological footprint analysis of Greater London. London: Chartered Institution of Wastes Management - Environmental Body, 2002.

BESTOR, T. Tsukiji: The Fish Market at the Center of the World. Berkeley and Los Angeles: University of California Press, 2004.

BROWNING, E. K.; ZUPAN, M.A. Microeconomic Theory and Applications. Reading, USA: Addison Wesley Publishing, 1999.

CATTON W. Overshoot: The Ecological Basis of Revolutionary Change. Champaign, Illinois: University of Illinois Press, 1980.

CHIRAS, D. D.; REGANOLD, J. P. Natural Resource Conservation, Management for a Sustainable Future. $10^{\text {th }} \mathrm{Ed}$. Upper Saddle River, NJ: Pearson Prentice Hall, 2010.

\section{Acknowledgements}

The authors thank the anonymous reviewers for their constructive and helpful comments. All miscalculations, mis-interpretations and other mistakes are the responsibility of the authors.

CHRISTENSEN, V.; GUENETTE, S.; HEYMANS, J. J.; WALTERS, C. J.; WATSON, R.; ZELLER, D.; PAULY, D. Hundred-year decline in North Atlantic predatory fishes. Fish and Fisheries, p. 1-24, 2003.

CLARK, G. Evolution of the global sustainable consumption and production policy and the United Nations Environment Programme's (UNEP) supporting activities. Journal of Cleaner Production, p. 1-7, 2006.

COINTREAU, S. Environmental Management of Urban Solid Waste in Developing Countries. Urban Development Technical Paper N.. 5. Washington, DC: The World Bank, 1982.

CORTAZZI, H. Modern Japan, a Concise Survey. Tokyo: The Japan Times, Ltd., 1994.

DICHTER, E. Motivating Human Behavior. New York: McGraw-Hill, 1971.

DREYFUS, T. Massive government subsidies bloat fishing industry and violate world trade rules: WWF calls for new international fisheries rules and mechanisms. Washington DC: World Wildlife Fund, 1998.

FOLKE, C.; JANSSON, A.; LARSSON, J.; COSTANZA, R. Ecosystem appropriation by cities. Ambio, v. 27, p. 167-172, 1997.

FOREIGN PRESS CENTER JAPAN. Facts and Figures of Japan 2004. Tokyo: Foreign Press Center, 2004.

FU, C.; HARASAWA, H.; KASYANOV, V.; KIM, J. W.; OJIMA, D.; WAN, Z.; ZHAO, S. Regional-global interactions in East Asia. In: TYSON, P.; FUCHS, R.; FU, C.; LEBEL L.; MITRA, A. P.: ODADA, E.; PERRY, J.; STEFFEN, W.; VIRJI, H. (Orgs.). Global-Regional Linkages in the Earth System. Berlin: Springer-Verlag, 2002.

FUJITA, K.; HILL, R. C. The zero waste city: Tokyo's quest for a sustainable environment. Journal of Comparative Policy Analysis: Research and Practice, v. 9, iss. 4, p. 405-425, 2007. 
GADDA, T. M. C. Understanding the Changing Appropriation of Natural Resources by Cities: A Case Study of Seafood Consumption in Tokyo from 1953 to 2003. In: Graduate School of Science and Technology. p. 115. Chiba, Dissertation ( $\mathrm{PhD}$ in Earth and Human Environmental Science) - Chiba University, 2006.

HEAD, J. Japan pushes whale meat revival. British Broadcasting Company, 2005.

HILBORN, R.; BRANCH, T. A.; ERNST, B.; MAGNUSSON, A.; MINTE-VERA, C. V.; SCHEUERELL, M. D.; VALERO, J. L. State of the World's Fisheries. Annual Review of Environment and Resources, v. 28, p. 359-399, 2003.

HONJO, M. The growth of Tokyo as a world city. In: LO, F.-c.; YEUNG, Y.-M. (Eds.). Globalization and the World of Large Cities. Tokyo: UNU Press, 1998. p. 109-131.

HONMA, A. Aquaculture in Japan. Tokyo: Japan FAO Association, 1993.

INSTITUTE FOR URBAN STRATEGIES. Global Power City Index, Yearbook 2011. Tokyo: Mori Memorial Foundation, 2012.

JACKSON, T.; MICHAELIS, L. Policies for sustainable consumption. Sustainable Development Commission, 2003.

JAPAN MINISTRY OF AGRICULTURE FORESTRY AND FISHERIES. Abstract of Statistics on Agriculture Forestry and Fisheries, 1977. Tokyo: Association of Agriculture-Forestry Statistics, 1978.

Abstract of Statistics on Agriculture Forestry and Fisheries, 1980. Tokyo: Association of Agriculture-Forestry Statistics, 1981.

. Abstract of Statistics on Agriculture Forestry and Fisheries, 1985. Tokyo: Association of Agriculture-Forestry Statistics, 1986.

Abstract of Statistics on Agriculture Forestry and Fisheries, 1996. Tokyo: Association of Agriculture-Forestry Statistics, 1997.

. Annual Report on the Developments in Japan's Fisheries in FY2002. 2002a. On-line: <http://www.maff.go.jp/ hakusyo/kaigai/fy2002.pdf > . Accessed on: 12/11/2005.

. Report on Agricultural, Forestry, and Fishery Trades in 2002. 2002b.

Annual Report on the Developments in the Fisheries Industry in FY 2003. 2003. On-line: <http://www.maff.go.jp/ hakusyo/kaigai/fy2003.pdf $>$. Accessed on: 12/11/2005.
. Annual Report on the Developments in the Fisheries in FY 2004: Part 1 Developments in the Fisheries. 2004. On-line $<$ http://www.maff.go.jp/hakusyo/kaigai/fy2004.pdf $>$. Accessed on 12/11/2005.

KASSER, T. The High Price of Materialism. Cambridge: MIT Press, Mass., 2002.

KIDOKORO, T.; ONISHI, T.; MARCOTULLIO, P. J. The impact of globalization and issues of metropolitan planning in Tokyo. In: LO, F.-C.; MARCOTULLIO, P. J. (Eds.). Globalization and the Sustainability of Cities in the Asia Pacific Region. Tokyo: UNU Press, 2001. p. 115-139.

KRONENBERG, J. Making consumption "reasonable". Journal of Cleaner Production, v. 15, issue 6, p. 557-566, 2007.

LARSEN, J. Wild fish catch hits limits - oceanic decline offset by increased fish farming. Washington DC: Earth Policy Institute, 2005.

LASH, J. Subsides and the decline of the world's fisheries. In: WORLD RESOURCES INSTITUTE. WRI Features, 2003.

LEE, K. N. Urban sustainability and the limits of classical environmentalism. Environment and Urbanization, v. 18, p. 9-22, 2006.

LINNER, B.-O. The Return of Malthus, Environmentalism and Post-war Population-Resource Crises. Isle of Harris, UK: The White Horse Press, 2003.

LOH, J. (Ed.). The Living Planet Report. Gland, Switzerland: WWF-World Wide Fund for Nature, 2004.

MATSUDA, Y. History of Fish Marketing and Trade with Particular Reference to Japan. In: IIFET (Ed.). International Institute of Fisheries Economics and Trade 2000 conference: Macrobehavior and Microresults. Oregon, USA: Corvallis, 2000.

McGRANAHAN, G.; JACOBI, P.; SONGSORE, J.; SURJADI, C.; KJELLEN, M. The Citizens at Risk, From Urban Sanitation to Sustainable Cities. London: Earthscan, 2001.

MILLENNIUM ECOSYSTEM ASSESSMENT. Ecosystems and Human Well-Being, Synthesis. Washington, DC: Island Press, 2005.

MYERS, N.; KENT, J. Perverse Subsidies. Washington DC: Island Press, 2001.

MYERS, R.; WORM B. Rapid worldwide depletion of predatory fish communities. Nature, v. 423, p. 280-282, 2003.

NEWMAN, P.; KENWORTHY, J. Sustainability and Cities. Washington DC: Island Press, 1999. 
PALOMARES. The Ecology Table. In: FROESE, R.; PAULY, D. (Eds.). FishBase 2000 - Concepts, Design and Data Sources, 2000. On-line: <http://www.fishbase.org/manual/english/ fishbasethe_ecology_table.htm $>$. Accessed on: 19/12/2012.

PAULY, D.; ALDER, J. Marine Fisheries Systems. In: MILLENNIUM ECOSYSTEM ASSESSMENT (Ed.). Condition and Trends Volume, Chapter 18. Washington, DC: Island Press, 2005. p. 477-511.

; BENNETT, E.; CHRISTENSEN, V.; TYEDMERS, P.; WATSON, R. The future of fisheries. Science, v. 302, p. 1359-1361, 2003.

; CHRISTENSEN, V. Primary production required to sustain global fisheries. Nature, v. 374, p. 255-257, 1995.

; DALSGAARD, J.; FROESE, R.; FRAN-

CISCO, Torres J. Fishing down marine food webs. Science, v. 279, p. 860-863, 1998.

REDEFINING PROGRESS. Sarasota County Ecological Footprint Assessment. Oakland: Redefining Progress, 2004. p. 5.

REES, W.; WACKERNAGEL, M. Urban ecology footprints: why cities cannot be sustainable - and why they a key to sustainability. Environmental Impact Assessment Review, Volume 16, Issue 4-6, p. 223-248, 1996.

REES, W. E. Globalization and sustainability: conflict or convergence? Bulletin of Science, Technology and Society, v. 22, p. 249-268, 2002.

RIDLEY, M. The Red Queen: Sex and the Evolution of Human Nature. New York: Macmillan Pub. Co., 1994.

SANNE, C. Willing consumers - or locked-in? Policies for a sustainable consumption. Ecological Economics, v. 42, p. 273-287, 2002.

SANTA MONICA SUSTAINABLE CITY PROGRAM; REDEFINING PROGRESS. Santa Monica's Ecological Footprint, 1990-2000. Santa Monica, CA: Environmental Programs Division, 2004.

SASSEN, S. The Global City: New York, London, Tokyo. Princeton: Princeton University Press, 1991.

SATTERTHWAITE, D. Sustainable cities or cities that contribute to sustainable development. Urban Studies, v. 34, p. 1667-1691, 1997.

SCHIERMEIER, Q. How many more fish in the sea? Nature, v. 419 , p. $662-665,2002$.
SEIDENSTICKER, E. Tokyo Rising, The City Since the Great Earthquake. Tokyo: Charles E. Tuttle Company, 1991.

SEA AROUND US PROJECT. Available at: <http://www. seaaroundus.org>. Access: nov. 2012.

SIMMS, A.; ORAM, J.; MacGILLIVRAY, A.; DRURY, J. Ghost Town Britain: The Threat from Economic Globalization to Livelihoods, Liberty and Local Economic Freedom. London: New Economics Foundation, 2002.

SIMON, J. L. The Ultimate Resource. Princeton: Princeton University Press, 1981.

STRATHMANN, R. R. Estimating the organic carbon content of phytoplankton from cell volume or plasma volume. Limnology and Oceanography, v. 12, p. 411-418, 1967.

SWARTZ, W. Growth of Japanese fisheries and fish consumption. In: Faculty of Graduate Studies. Vancouver: University of British Columbia, 2004.

THE ECONOMIST. Asia: The politics of whaling. The Economist, p. 42, 2000.

THE ECONOMIST. Asia: Depends on where you are: Japan's economic recovery. The Economist, p. 66, 2006.

UK CABINET OFFICE - THE STRATEGY UNIT. Food matters: Towards a strategy for the 21 st century. London: Cabinet Office of the UK, 2008a.

Food: An analysis of the issues. London: Cabinet Office of the UK, 2008b.

UK SUSTAINABLE DEVELOPMENT COMMISSION. Sustainability implications of the little red tractor scheme. London: Report for the Sustainable Development Commission, 2005.

Setting the table: Advice to government on priority elements of sustainable diets. London: Report for the Sustainable Development Commission, 2009.

UN-HABITAT. Changing consumption patterns in human settlements. In: E. C. f. E. (ECE) (Ed.). Workshop on Encouraging Local Initiatives Towards Sustainable Consumption Patterns. Vienna, Austria: United Nations, 1997.

VITOUSEK, P. M.; MOONEY, H.; LUBCHENKO, J.; MELILLO, J. Human domination of Earth's ecosystems. Science, v. 277, p. 494-499, 1997.

WACKERNAGEL, M.; REES, W. Our Ecological Footprint. Gabriola Island, Canada: New Society Publishers, 1996.

; SCHULZ, N. B.; DEUMLING, D.; LINARES, A. C.; JENKINS, M.; KAPOS, V.; MONFREDA, C.; LOH, J.; 
MYERS, N.; NORGAARD, R.; RANDERS, J. Tracking ecological overshoot of the human economy. Proceedings of the National Academy of Sciences of the United States of America, v. 99, p. 9266-9271, 2002.

WADA, Y. The Myth of "Sustainable Development": The Ecological Footprint of Japanese Consumption. In:

School of Community and Regional Planning. Vancouver: University of British Columbia, 1999.

WARREN-RHODES, K.; KOENIG, A. Ecosystem appropriation by Hong Kong and its implications for sustainable development. Ecological Economics, v. 39, p. 347-359, 2001.

WATANABE, Z. Once Influenced by Foreign Foods, Japanese Food Now Influences the Diets of the World. Kikkoman Institu- te for International Food Culture, 2005. On-line: $<$ http://kiifc. kikkoman.co.jp/english/bulletin/index.html $>$, N. 10. Accessed on: 01/11/2005.

WATSON, R.; PAULY, D. Systematic distortions in the world fisheries catch trends. Nature, v. 414, p. 536, 2001.

WORLD BANK. World Development Report. New York: World Bank and Oxford University Press, 1992.

WORM, B.; BARBIER, E. B.; BEAUMONT, N.; DUFFY, J. E.; FOLKE, C.; HALPERN, B. S.; JACKSON, J. B. C.; LOTZE, H. K.; MICHELI, F.; PALUMBI, S. R.; SALA, E.; SELKOE, K. A.; STACHOWICZ, J. J.; WATSON, R. Impacts of biodiversity loss on ocean ecosystem services. Science, v. 314, p. 787-790, 2006.

Recebido em 4 de março de 2012. Aceito em 19 de junho de 2012. Publicado em dezembro de 2012. 